\title{
KESALAHAN PENGGUNAAN HURUF KAPITAL PADA KARANGAN DESKRIPSI TERHADAP KEMAMPUAN MENULIS MAHASISWAUNIVERSITAS INDRAPRASTA PGRI
}

\author{
Ade Siti Haryanti \\ adesiti.haryanti@unindra.ac.id
}

Pendidikan Bahasa dan Sastra Indonesia, Fakultas Keguruan dan Ilmu Pendidikan Universitas Indraprasta PGRI

\begin{abstract}
Abstrak
Tujuan dari penelitian ini adalah untuk mengetahui kesalahan penggunaan huruf kapital pada karangan deskripsi mahasiswa Universitas Indraprasta PGRI. Metode penelitian yang digunakan dalam penelitian ini adalah metode kualitatif yang termasuk dalam penelitian kebahasaan. Berdasarkan penelitian dan pendeskripsian mengenai kesalahan penggunaan huruf kapital pada karangan deskripsi mahasiswa Semester 3 (R3A) yang mengikuti mata kuliah Menulis Universitas Indraprasta PGRI, dapat disimpulkan bahwa terdapat sebanyak 101 kesalahan dalam menggunakan huruf kapital dari 20 karangan deskripsi mahasiswa semester 3 kelas R3A yang meliputi: 1) Huruf kapital dipakai sebagai huruf pertama awal kalimat, sebanyak 25 kesalahan 25\%. 2) Huruf kapital dipakai sebagai huruf pertama nama tahun, hari, bulan, hari besar atau hari raya, sebanyak 10 kesalahan 10\%. 3) Huruf kapital dipakai sebagai huruf pertama nama geografis, sebanyak 35 kesalahan 34\%. 4) Huruf kapital dipakai sebagai huruf pertama unsur-unsur nama orang termasuk nama julukan dan singkatan, sebanyak 23 kesalahan 23\%. 5) Huruf kapital dipakai sebagai huruf pertama setiap kata agama, kitab suci, dan Tuhan, termasuk sebutan dan kata ganti untuk Tuhan, sebanyak 8 kesalahan $8 \%$.
\end{abstract}

\section{Abstract}

The purpose of this study is to find out the error in using capital letters in the description of students of Indraprasta PGRI University. The research method used in this study is a qualitative method included in linguistic research. Based on the research and description of capital letter usage errors in the Semester 3 Student description essay (R3A) which follows the Writing course of the Indraprasta PGRI University, it can be concluded that there are 101 errors in using capital letters of 20 essay descriptions of R3A class 3 semester students which include: 1) Capital letters are used as the first letters of the beginning of a sentence, 25 errors of 25\%.2) Capital letters are used as the first letter of the name of the year, day, month, as many as 10 errors of 10\%.3) Capital letters are used as the first letter of geographical name, as many as 35 errors 34\%. 4) Capital letters are used as the first letters of people's names including nicknames and abbreviations, 23 errors 23\%. 5) Capital letters are used as the first letter of every word of religion, scripture, and GOD, including designations and pronouns for GOD, as many as 8 errors of $8 \%$.

\section{PENDAHULUAN}

Menulis merupakan proses mengutarakan pikiran, perasaan, penginderaan, khayalan, kemauan, keyakinan, dan pengalaman yang disusun dengan lambang-lambang grafik secara tertulis yang bertujuan komunikasi baik lisan maupun tulisan. Dalam proses menulis dibutuhkan konsentrasi dan tenaga, karena dalam prosesnya seringkali mendapatkan hambatan-hambatan yang terjadi. Menulis merupakan suatu proses berpikir yang sangat aktif, karena dalam proses keterampilan menulis seseorang dituntut untuk dapat memusatkan perhatian. Pada kenyataannya, mahasiswa yang terampil menulis tidak akan mengalami kesulitan dalam menyelesaikan tugas-tugas kuliah seperti menyusun makalah, laporan tertulis, dan membuat karangan. Namun masih banyak mahasiswa yang menganggap bahwa 
kegiatan menulis merupakan suatu beban berat.Anggapan itu timbul karena kegiatan menulis memang meminta banyak tenaga, waktu, serta perhatian yang sungguh-sungguh.

Kesalahan penulisan yang sering terjadi yaitu, kesalahan penggunaan ejaan bahasa Indonesia. Kaidah ejaan bahasa Indonesia merupakan salah satu faktor penting dalam hal kegiatan menulis. Pemilihan kata berkaitan erat dengan sintaksis, kaidah makna, kaidah hubungan sosial, dan kaidah mengarang. Kaidah-kaidah ini sangat mendukung dalam hal menulis, agar hasil tulisannya memiliki makna dan dapat dipahami oleh seorang pembaca. Kesalahan penulisan dikategorikan ke dalam kesalahan bahasa tulis. Kesalahan berbahasa terjadi karena adanya penyimpangan terhadap kaidah-kaidah bahasa yang dilakukan oleh mahasiswa. Penyimangan tersebut biasanya bersifat sistematis. Dalam kegiatan menulis mahasiswa hanya memperhatikan hasilnya saja, bukan suatu proses penulisan kaidah bahasa yang benar. Padahal kenyataannya suatu tulisan yang sudah sempurna menurut segi isi belum tentu dikatakan tulisan yang baik, apabila banyak kesalahan ejaan dan tanpa memperhatikan ejaan yang benar.

Menulis deskripsi merupakan salah satu jenis karangan atau karya tulis yang bersifat meggambarkan atau melukiskan suatu tempat, keadaan, atau benda dalam kalimat. Menulis karangan deskripsi memiliki langkah-langkah yang harus

352 | Jurnal Kredo Vol. 2 No. 2 April 2019 ditempuh. Pertama, harus melakukan pengamatan terlebih dahulu. Kedua, menjabarkan apa yang kita lihat. Ketiga, harus logis dalam menyusun rinciannya, jika penyusunannya tidak logis maka akan membuat seorang pembaca menjadi bingung terhadap hasil tulisannya. Berdasarkan latar belakang masalah yang telah dikemukakan, maka peneliti akan melakukan analisis dengan judul "Kesalahan Penggunaan Huruf Kapital Pada Karangan Deskripsi Terhadap Kemampuan Menulis Mahasiswa Universitas Indraprasta PGRI".

\section{KAJIAN TEORI}

Kesalahan berbahasa menurut Tarigan (2011: 126) mengatakan bahwa "kesalahan berbahasa tidak hanya dibuat oleh siswa yang mempelajari bahasa kedua (B2), tetapi juga oleh siswa yang mempelajari bahasa pertama (B1). Hal ini menunjukkan bahwa kesalahan berbahasa itu erat kaitannya dengan pembelajaran bahasa, baik dalam pembelajaran bahasa kedua (B2) ataupun bahasa pertama (B1). "dapat dikatakan bahwa kesalahan berbahasa dapat dialami oleh seseorang yang mempelajari bahasa pertama ataupun bahasa kedua.

Berdasarkan pendapat di atas dapat disimpulkan bahwa analisis kesalahan berbahasa yaitu penyelidikan terhadap kesalahan dalam berbahasa yang menyimpang dari kaidah bahasa dan sudah 
menjadi kebiasaan dalam masyarakat yang terjadi karena kurangnya kompetensi belajar. Menurut Prihantini (2015: 104) berpendapat bahwa "ejaan merupakan keseluruhan peraturan mengenai bagaimana menggambarkan lambang-lambang bunyi ujaran dan bagaimana inter-relasi antara lambang-lambang itu (pemisah dan penggabungannya) dalam suatu bahasa".

Berdasarkan pendapat di atas, dapat disimpulkan bahwa ejaan yaitu pengaturan mengenai lambang bunyi bahasa secara keseluruhan, bagaimana cara menuliskan bahasa dari kata, kalimat, hingga tanda baca serta hubungannya dengan lambang bunyi bahasa. Kesalahan umum dalam pemakaian huruf adalah kesalahan pemakaian huruf kapital karena huruf yang sering digunakan secara respektif, (Matanggui, 2014: 22). Artinya pemakaian bahasa mengaitkan pemakaian huruf kapital dengan rasa hormat terhadap seseorang, lembaga, aliran, paham, ataupun sesuatu yang dianggapnya sakral, sesuatu akan dituliskannya dengan huruf awal kapital maupun bukan nama diri.

Menurut Hasani (2005: 38) bahwa karangan deskripsi adalah karangan yang menekankan pada pemerian yang berusaha memberi perincian terhadap suatu objek secara detail atau melukiskan suatu keadaan secara detail dengan kemampuan menggunakan penginderaan yang baik, sehingga pembaca seolah-olah dapat merasakan sesuatu yang dilukiskan tersebut. Dari pengertian di atas, maka dapat disimpulkan bahwa tulisan deskripsi adalah tulisan yang menggambarkan atau melukiskan berdasarkan kesan dari pengamatan, perasaan, dan pengalaman penulisnya. Sehingga pembaca dituntut untuk dapat berimajinasi seolah-olah mereka melihat, mendengarkan, dan merasakan apa yang penulis lukiskan dalam bentuk tulisan.

\section{METODE PENELITIAN}

Metode penelitian yang digunakan dalam penelitian ini adalah metode kualitatif yang termasuk dalam penelitian kebahasaan. Menurut Semi (2012: 28) "Penelitian kualitatif dilakukan dengan tidak mengutamakan pada angka-angka, tetapi mengutamakan kedalaman penghayatan terhadap interaksi antara konsep yang sedang dikaji secara empiris. Dengan menggunakan pendekatan kualitatif ini peneliti berusaha mengkaji permasalahan secara mendalam dan detail.

\section{TEKNIK PENELITIAN}

Teknik penelitian yang digunakan dalam penelitian ini adalah teknik analisis isi dengan menggunakan dokumentasi.Seperti yang dikemukakan Sugiyono (2016: 14) "metode penelitian kualitatif sering disebut penelitian naturalistik 
karena penelitiannya dilakukan pada kondisi yang alami (natural setting). "dalam penggunaan metode kualitatif juga ada waktu kapan metode tersebut digunakan dan dengan teknik tertentu. Ada yang menggunakan metode kualitatif, dengan teknik wawancara yang mandalam, observasi berperan serta dan dokumentasi. Melalui hasil dokumentasi peneliti dituntut untuk dapat menginterpretasikan sesuatu dengan penjelasan yang tepat dan alamiah. Setelah karangan dibaca, karangan diteliti dengan cermat untuk menemukan kesalahan penggunaan huruf kapital yang akan dijadikan data.

\section{FOKUS PENELITIAN}

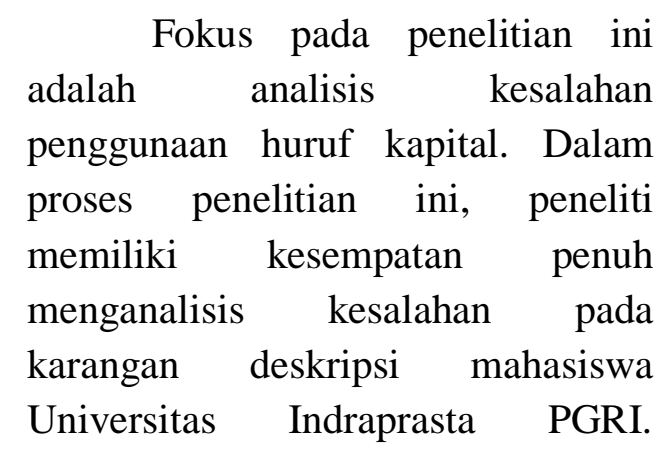

Penentuan subfokus dalam penelitian ini bertumpu pada landasan teoretik penggunaan huruf kapital sesuai dengan kaidah bahasa Indonesia. Peneliti menentukan lima aspek kesalahan yang sering terjadi dalam penggunaan huruf kapital yaitu: 1) huruf kapital sebagai huruf pertama awal kalimat, 2) huruf kapital dipakai sebagai huruf pertama nama tahun, bulan, hari, dan hari besar atau hari raya, 3) huruf kapital dipakai sebagai huruf pertama nama 354 | Jurnal Kredo Vol. 2 No. 2 April 2019 geografi, 4) huruf kapital dipakai sebagai huruf pertama unsur-unsur nama orang, termasuk julukan, 5) huruf kapital dipakai sebagai huruf pertama unsur singkatan nama gelar.

\section{HASIL DAN PEMBAHASAN}

Penelitian ini dilakukan Penelitian ini dilakukan di Universitas Indraprasta PGRI beralamat di Jalan Raya Tengah No. 80, Kelurahan. Gedong, Kecamatan. Pasar Rebo, Jakarta Timur. Pelaksanaan penelitian ini pada semester Gasal 2018. Untuk uji coba dilakukan pada mahasiswa semester 3, yang mengikuti Mata Kuliah Menulis.

\begin{tabular}{cccc}
\multicolumn{2}{r}{ Sampel yang } & \multicolumn{2}{c}{ diambil } \\
sebanyak & 20 & karangan dari & 40 \\
karangan & mahasiswa semester & 3.
\end{tabular}
Penelitian akan menganalisis kesalahan penggunaan huruf kapital pada karangan deskripsi yang telah dibuat oleh mahasiswa tersebut berdasarkan subfokus yang telah ditentukan.Peneliti menjadikan karangan deskripsi sebagai objek penelitian ini, karena ingin mengetahui hasil pengamatan dan pendeskripsian mahasiswa mengenai sesuatu yang dekat dengan keseharian mahasiswa. Untuk memudahkan mahasiswa, maka peneliti memberikan sebuah tema “indahnya alam ini". Dengan begitu mahasiswa diharapkan mampu mendeskripsikan apa yang ia lihat, dengar, dan rasakan dalam bentuk tulisan. 
Deskripsi temuan penelitian ini akan menyajikan berbagai temuan data tentang kesalahan penggunaan huruf kapital mengenai: (1) Huruf kapital sebagai huruf pertama awal kalimat, (2) huruf kapital dipakai sebagai huruf pertama nama tahun, bulan, hari, dan hari besar atau hari raya, (3) Huruf kapital dipakai sebagai huruf pertama nama geografis, (4) Huruf kapital dipakai sebagai huruf pertama unsur-unsur nama orang, termasuk nama julukan dan singkatan, (5) Huruf kapital dipakai sebagai huruf pertama setiap kata agama, kitab suci, dan Tuhan, termasuk sebutan dan kata ganti untuk Tuhan.Berdasarkan analisis pada karangan deskripsi mahasiswa semester 3 yang menggambil mata kuliah menulis dan memperoleh data yang lengkap, peneliti akan mendeskripsikan terlebih dahulu data yang diperoleh, sebagai berikut:

\section{Analisis Kesalahan Penggunaan}

\section{Huruf Kapital}

1. M. Faisal Azmi dalam karangannya ditemukan beberapa kesalahaan dalam penggunaan huruf kapital pada huruf pertama nama geografis (Tengah malam datang untuk segera beranjak keluar rumah, untuk menghirup udara segar pagi esok di kaki G. gede. Sesampainya di Pos jangan lupa untuk mengisi perut terlebih dahulu agar tenaga tidak lemah.), Huruf kapital sebagai huruf pertama awal kalimat (banyak orang-orang beranggapan naik gunung atau melakukan pendakian itu hal yang disepelekan), huruf kapital dipakai sebagai huruf pertama nama tahun, bulan, hari, dan hari besar atau hari raya (kami menginap di kaki Gunung Gede hingga hari minggu, setelah kami menyelesaikan semua misi yang kami susun terlebih dahulu bersama Tim.), Huruf kapital sebagai huruf pertama awal kalimat dan huruf kapital dipakai sebagai huruf pertama nama tahun, bulan, hari, dan hari besar atau hari raya (kegiatan ini sering kami lakukan untuk mempererat tali silahturahmi. Biasanya kami pergi di harihari libur nasional ataupun hari sabtu hingga minggu).

2. Indah Uswatun dalam karangannya ditemukan beberapa kesalahaan dalam penggunaan huruf kapital. Seperti Huruf kapital dipakai sebagai huruf pertama nama geografis (Kampung Wakaf dan kampung kadu tepatnya desa Banyuasih, kami berangkat ke sana menggunakan Tronton. Dan ditemukan 2 kali huruf kapital dipakai sebagai huruf pertama nama tahun, bulan, hari, dan hari besar atau hari raya. (Kami pergi ke sana bertepatan dengan hari libur nasional 17 agustus), (Mengingat Karena besok hari kamis kami sudah harus mesuk kuliah kembalih, sehingga kami memutuskan untuk tidak menginap di sana). 
3. Shinta Destiani dalam karangannya ditemukan beberapa kesalahaan dalam penggunaan huruf kapital. Seperti, Huruf kapital dipakai sebagai huruf pertama nama geografis (Untuk pergi ke kota malang, saya memutuskan untuk menggunakan kereta), Huruf kapital sebagai huruf pertama awal kalimat dan Huruf kapital dipakai sebagai huruf pertama setiap kata agama, kitab suci, dan Tuhan (ada banyak pohon yang tertiup angin serta kerbau yang sedang membajak sawah dan kita dapat mensyukuri nikmat yang diberikan tuhan kepada kita bahwa ala mini sangat indah), Huruf kapital dipakai sebagai huruf pertama unsur-unsur nama orang, termasuk nama julukan dan singkatan (ketika pagi menjelang udara dipagi hari sangat dingin, di situlah burung mulai berkicauan dan para petani pun sudah mulai melakukan aktivitasnya untuk memanen padi).

4. Rusda Sabila dalam karangannya ditemukan beberapa kesalahaan dalam penggunaan huruf kapital, seperti, Huruf kapital dipakai sebagai huruf pertama nama geografis (karena memiliki kekayaan alam yang sangat indah dan pastinya sangat menggoda bagi para pelancong yang berasal dari sekitar bogor, Jakarta, depok, dan sekitarnya), Huruf kapital dipakai sebagai huruf pertama unsur-unsur nama orang, termasuk nama julukan dan singkatan (menjajakan jajanan oleh-oleh yang nantinya akan di bawa oleh pelancong), Huruf kapital sebagai huruf pertama awal kalimat (wisata alam puncak banyak tersedia villa dan penginapan).

5. Melina Anjarwati dalam karangannya ditemukan beberapa kesalahan dalam penggunaan huruf kapital., Huruf kapital dipakai sebagai huruf pertama nama geografis (Danau dora yang terletak di daerah kab. cibinong. Taman ini terkenal dengan sebutan danau dora.), Huruf kapital sebagai huruf pertama awal kalimat (pemandangan yang sejuk dan asri, memandangi di tengah-tengah), Huruf kapital dipakai sebagai huruf pertama unsur-unsur nama orang, termasuk nama julukan dan singkatan (Disekitaran Danau tersebut banyak sekali penjual yang menjajakan makanan dan minuman).

6. Putri Rostiana dalam karangannya ditemukan beberapa kesalahan dalam penggunaan huruf kapital, seperti, Huruf kapital dipakai sebagai huruf pertama nama geografis (Pantai Indrayanti gunung kidul sekarang telah menjadi salah satu wisata yang paling diminati di kawasan 
Yogyakarta), dan (Pantai indrayanti juga dikenal dengan suasana pantainya seperti di pulai bali).

7. Hani Raditia. P dalam karangannya ditemukan beberapa kesalahan dalam penggunaan huruf kapital, seperti Huruf kapital sebagai huruf pertama awal kalimat dan Huruf kapital dipakai sebagai huruf pertama nama geografis (hutan pinus mangunan adalah sebuah hutan yang indah dan sejuk, terletak di wonosari jawa tengah).

8. Kartika. W dalam karangannya ditemukan beberapa kesalahan dalam penggunaan huruf kapital, seperti huruf pertama awal kalimat dan Huruf kapital dipakai sebagai huruf pertama nama geografis (pantai lariti merupakan salah satu pantai yang ada di provinsi NTB berada di bima, pantai nan indah dan menawan).

9. Rufita Ayu. N dalam karangannya ditemukan beberapa kesalahan dalam penggunaan huruf kapital, seperti huruf kapital dipakai sebagai huruf pertama nama tahun, bulan, hari, dan hari besar atau hari raya (Pada selasa siang seusai ujian Tengah Semester hari terakhir), Huruf kapital dipakai sebagai huruf pertama nama geografis (Saya dan teman-teman merencanakan unruk pergi ke curug bidadari), dan (di jalan raya bogor hujan turun sangat deras, kamipun memakai jas hujan agar kami tidak basah kuyub).

10. Rafli Yulmaren dalam karangannya ditemukan beberapa kesalahan dalam penggunaan huruf kapital, seperti Huruf kapital sebagai huruf pertama awal kalimat, Huruf kapital dipakai sebagai huruf pertama nama geografis, dan Huruf kapital dipakai sebagai huruf pertama unsurunsur nama orang, termasuk nama julukan dan singkatan (sayangnya wisata-wisata yang ada di bogor banyak dikelola oleh oknum preman, ormas, ataupun karang taruna setempat. mereka mematok harga tiket yang begitu tinggi)

11. Ahmad Suhaimi dalam karangannya ditemukan beberapa kesalahan dalam penggunaan huruf kapital, seperti Huruf kapital dipakai sebagai huruf pertama setiap kata agama, kitab suci, dan Tuhan, termasuk sebutan dan kata ganti untuk Tuhan (Katanya Indonesia itu negara yang bertanah surga.), Huruf kapital dipakai sebagai huruf pertama unsur-unsur nama orang, termasuk nama julukan dan singkatan (Indonesia adalah negara yang sangat kucintai dan kusayangi, aku bangga menjadi pemuda bangsa negara yang bertanah surga ini), Huruf kapital dipakai sebagai huruf pertama 
(orang luar negeri bilang, bahwa Indonesia).

12. Irwandi Agustian dalam karangannya ditemukan beberapa kesalahan dalam penggunaan huruf kapital, seperti Huruf kapital dipakai sebagai huruf pertama nama geografis,Huruf kapital dipakai sebagai huruf pertama unsurunsur nama orang, termasuk nama julukan dan singkatan (Gunung prau memiliki ketinggian 2.565 mdpl yang merupakan puncak tertinggi di kawasan Pegunungan Dieng).

13. Ika Witantri dalam karangannya ditemukan beberapa kesalahan dalam penggunaan huruf kapita, seperti Huruf kapital dipakai sebagai huruf pertama nama geografis,Huruf kapital dipakai sebagai huruf pertama unsurunsur nama orang, termasuk nama julukan dan singkatan (Bogor adalah salah satu kota yang terletak di Pulau jawa. Kota ini mendapat julukan kota hujan.), Huruf kapital dipakai sebagai huruf pertama (banyak orang memilih untuk berjalan kaki menuju ke sana.), huruf kapital dipakai sebagai huruf pertama nama tahun, bulan, hari, dan hari besar atau hari raya (Kebon Raya Bogor banyak dikunjungi oleh masyarakat di hari libur maupun hari minggu).

14. Nabila Dwi. A dalam karangannya ditemukan beberapa kesalahan dalam

358 | Jurnal Kredo Vol. 2 No. 2 April 2019 penggunaan huruf kapital, seperti huruf kapital dipakai sebagai huruf pertama nama tahun, bulan, hari, dan hari besar atau hari raya, Huruf kapital dipakai sebagai huruf pertama nama geografis (Tahun lalu liburan lebaran, saya bersama keluarga mengunjungi tempat wisata yang dikenal dengan nama waduk jatiluhur yang terletak dikota Purwakarta.), Huruf kapital dipakai sebagai huruf pertama (saya sangat menyukai tempat tersebut), Huruf kapital dipakai sebagai huruf pertama setiap kata agama, kitab suci, dan Tuhan, termasuk sebutan dan kata ganti untuk Tuhan (Sungguh indahnya alam ini engkau ciptakan sehingga kami merasakan).

15. Natalia dalam karangannya ditemukan beberapa kesalahan dalam penggunaan huruf kapital, seperti Huruf kapital dipakai sebagai huruf pertama nama geografis, (4) Huruf kapital dipakai sebagai huruf pertama unsur-unsur nama orang, termasuk nama julukan dan singkatan (Banyak hal indah yang telah tuhan ciptakan untuk bisa dirasakan oleh setiap makhluk hidup di bumi), Huruf kapital dipakai sebagai huruf pertama (kehidupan di bumi lambat laun mengalami kemunduran).

16. Dipa Wahidah dalam karangannya ditemukan 
beberapa kesalahan dalam penggunaan huruf kapital, huruf kapital dipakai sebagai huruf pertama nama tahun, bulan, hari, dan hari besar atau hari raya, dan seperti Huruf kapital sebagai huruf pertama awal kalimat (Pada pertengahan bulan September hapir setiap harinya kota Jakarta diguyur hujan.), dan (terkadang hujan tidak menentu, bisa pagi, siang, dan malam).

17. Risqi Aulia dalam karangannya ditemukan beberapa kesalahan dalam penggunaan huruf kapital. Huruf kapital dipakai sebagai huruf pertama nama geografis, (Sawah ini diberi nama oleh warga setempat yaitu sawah indah), Huruf kapital sebagai huruf pertama awal kalimat, huruf kapital dipakai sebagai huruf pertama nama geografis, huruf kapital dipakai sebagai huruf pertama unsur-unsur nama orang, termasuk nama julukan dan singkatan (sawah ini berada di tengah-tengah desa terpencil sehingga tiak ada gunung hanya saja sawah yang ditanami oleh petani yang kemungkinan mempunyai sawah tersebut.).

18. Dwi Rizki dalam karangannya ditemukan beberapa kesalahan dalam penggunaan huruf kapital. Huruf kapital dipakai sebagai huruf pertama nama geografis (Pagi menjelang, metahari pun menyongsong indahnya dari arah timur), Huruf kapital dipakai sebagai huruf pertama unsur-unsur nama orang, termasuk nama julukan dan singkatan, huruf kapital dipakai sebagai huruf pertama setiap kata agama, kitab suci, dan Tuhan (Saya melihat ada petani yang pergi ke sawah dan mereka akan kembali pulang kerumah pada saat kumandang Adzan dzuhur nanti.), Huruf kapital dipakai sebagai huruf pertama setiap kata agama, kitab suci, dan Tuhan (Pantai Slili merupakan surga terpencil yang dimiliki oleh kota Yogyakarta.).

19. Andina Putri dalam karangannya ditemukan beberapa kesalahan dalam penggunaan huruf kapital, seperti huruf kapital sebagai huruf pertama awal kalimat, huruf kapital dipakai sebagai huruf pertama nama geografis, huruf kapital dipakai sebagai huruf pertama unsur-unsur nama orang, termasuk nama julukan dan singkatan (perjalanan menuju Pantai Slili dari kota yogya memakan waktu 2 jam dengan jarak 22 km),

20. Mad Soleh dalam karangannya ditemukan beberapa kesalahan dalam penggunaan huruf kapital seperti huruf kapital dipakai sebagai huruf pertama nama geografis (Bukit pelangi merupakan suatu tempat di daerah Kabupaten Bogor yang sangat indah), sebagai huruf pertama awal kalimat (walau jalan yang dilewati banyak 
tanjakan dan turunan), Huruf kapital dipakai sebagai huruf pertama setiap kata agama, kitab suci, dan Tuhan (Bermalam di Bukit Pelangi tidak kalah indah karena kita bisa menikmati kelip-kelip bintang ciptaannya), dan huruf kapital dipakai sebagai huruf pertama nama tahun, bulan, hari, dan hari besar atau hari raya, Huruf kapital dipakai sebagai huruf pertama nama geografis, (Pagi hari di bukit pelangi, kesibukan masyarakat sekitar mulai terlihat, ada seorang petani yang bergegas pergi ke sawah sambil membawa cangkul, dan adapaula masyarakat yang membawa hasil panennya ke pasar).

Berikut ini merupakan hasil rekapitulasi frekuensi kesalahaan penggunaan huruf kapital mahasiswa semester 3 Universitas Indraprasta PGRI.

Tabel 1

Rekapitulasi Frekuensi Kesalahan Penggunaan Huruf Kapital

\begin{tabular}{|c|l|c|c|c|c|c|}
\hline \multirow{2}{*}{ 之 } & \multicolumn{1}{|c|}{$\begin{array}{l}\text { Nama } \\
\text { Mahasiswa }\end{array}$} & \multicolumn{4}{|c|}{$\begin{array}{c}\text { Aspek } \\
\text { Kesalahan }\end{array}$} & \multicolumn{2}{|c|}{} \\
\cline { 3 - 6 } & & $\mathbf{1}$ & $\mathbf{2}$ & $\mathbf{3}$ & $\mathbf{4}$ & $\mathbf{5}$ \\
\hline 1 & $\begin{array}{l}\text { M. Faisal } \\
\text { Azmi }\end{array}$ & 2 & 2 & 1 & - & - \\
\hline 2 & Ida Uswatun & - & 2 & 1 & - & - \\
\hline 3 & $\begin{array}{l}\text { Shinta } \\
\text { Destiani }\end{array}$ & 1 & - & 2 & 2 & 1 \\
\hline
\end{tabular}

360 | Jurnal Kredo

Vol. 2 No. 2 April 2019

\begin{tabular}{|c|l|c|c|c|c|c|}
\hline 4 & Rusda Sabila & 1 & - & 2 & 3 & 1 \\
\hline 5 & $\begin{array}{l}\text { Melina } \\
\text { Anjarwati }\end{array}$ & 1 & - & 2 & 1 & - \\
\hline 6 & $\begin{array}{l}\text { Putri } \\
\text { Rostiana }\end{array}$ & 1 & - & 3 & 1 & - \\
\hline 7 & $\begin{array}{l}\text { Hani Raditia. } \\
\text { P }\end{array}$ & 2 & 1 & 1 & - & - \\
\hline 8 & Kartika. W & 3 & - & 2 & - & - \\
\hline 9 & Rufita Ayu & 2 & 1 & 2 & - & - \\
\hline 10 & $\begin{array}{l}\text { Rafli } \\
\text { Yulmaren }\end{array}$ & 1 & - & 2 & 1 & - \\
\hline 11 & $\begin{array}{l}\text { Ahmad } \\
\text { Suhaimi }\end{array}$ & 1 & - & 1 & 2 & 1 \\
\hline 12 & $\begin{array}{l}\text { Irwandi } \\
\text { Agustian }\end{array}$ & 1 & - & 1 & 2 & - \\
\hline 13 & Ika Wintarti & 1 & 1 & 2 & 2 & - \\
\hline 14 & Nabila Dwi & 1 & 1 & 2 & 1 & 1 \\
\hline 15 & Natalia & 1 & - & 2 & - & 1 \\
\hline 16 & $\begin{array}{l}\text { Dipa } \\
\text { Wahidah }\end{array}$ & 1 & 1 & 1 & 2 & - \\
\hline 17 & Risqi Aulia & 1 & 1 & 2 & 1 & - \\
\hline 18 & Dwi Rizki & 2 & - & 1 & 2 & 1 \\
\hline 19 & Andina Putri & 1 & - & 3 & 2 & 1 \\
\hline 20 & Mad Soleh & 1 & - & 2 & 1 & 1 \\
\hline & Jumlah & $\mathbf{2 5}$ & $\mathbf{1 0}$ & $\mathbf{3 5}$ & $\mathbf{2 3}$ & $\mathbf{8}$ \\
\hline Desipsi & & & & & & \\
\hline & & & & & \\
\hline
\end{tabular}

kesalahan penggunaan huruf kapital sebagai berikut:

1. M Faizal Azmi terdapat 5 kesalahan dalam karangan yang dia tulis, diantaranya dalam 
penulisan huruf kapital sebagai huruf pertama awal kalimat ditemukan sebanyak 2 kali, huruf kapital dipakai sebagai huruf pertama nama tahun, bulan, hari, dan hari besar atau hari raya ditemukan sebanyak 2 kali, dan huruf kapital dipakai sebagai huruf pertama nama geografis sebanyak 1 kali.

2. Ida Uswatun terdapat 3 kesalahan dalam karangan yang dia tulis, diantaranya dalam penulisan huruf kapital dipakai sebagai huruf pertama nama tahun, bulan, hari, dan hari besar atau hari raya sebanyak 2 kali, dan huruf kapital dipakai sebagai huruf pertama nama geografis sebanyak 1 kali.

3. Shinta Destiani terdapat 6 kesalahan dalam karangan yang dia tulis, diantaranya dalam penulisan huruf kapital sebagai huruf pertama awal kalimat sebanyak 1 kali, Huruf kapital dipakai sebagai huruf pertama nama geografis sebanyak 2 kali, Huruf kapital dipakai sebagai huruf pertama unsur-unsur nama orang, termasuk nama julukan dan singkatan sebanyak 2 kali, dan Huruf kapital dipakai sebagai huruf pertama setiap kata agama, kitab suci, dan Tuhan, termasuk sebutan dan kata ganti untuk Tuhan sebanyak 1 kali.

4. Rusda Sabila terdapat 7 kesalahan dalam karangan yang dia tulis, diantaranya dalam penulisan huruf kapital sebagai huruf pertama awal kalimat sebanyak 1 kali, huruf kapital dipakai sebagai huruf pertama nama geografis sebanyak 2 kali kesalahan, huruf kapital dipakai sebagai huruf pertama unsurunsur nama orang, termasuk nama julukan dan singkatan sebanyak 3 kali kesalahan, dan huruf kapital dipakai sebagai huruf pertama setiap kata agama, kitab suci, dan Tuhan, termasuk sebutan dan kata ganti untuk Tuhan sebanyak 1 kali kesalahan.

5. Melina Anjarwati terdapat 4 kesalahan dalam karangan yang dia tulis, diantaranya dalam penulisan huruf kapital sebagai huruf pertama awal kalimat sebanyak 1 kali, Hhruf kapital dipakai sebagai huruf pertama nama geografis sebanyak 2 kali kesalahan, dan huruf kapital dipakai sebagai huruf pertama unsur-unsur nama orang, termasuk nama julukan dan singkatan sebanyak 1 kali kesalahan.

6. Putri Rostiana terdapat 5 kesalahan dalam karangan yang dia tulis, diantaranya dalam penulisan huruf kapital sebagai huruf pertama awal kalimat sebanyak 1 kali kesalahan, huruf kapital dipakai sebagai huruf pertama nama geografis sebanyak 3 kali kesalahan, dan huruf kapital dipakai sebagai huruf pertama unsur-unsur nama orang, termasuk nama julukan 
dan singkatan sebanyak 1 kali kesalahan.

7. Hani Raditia. $\mathrm{P}$ terdapat 4 kesalahan dalam karangan yang dia tulis, diantaranya dalam penulisan huruf kapital sebagai huruf pertama awal kalimat sebanyak 2 kali kesalahan, huruf kapital dipakai sebagai huruf pertama nama tahun, bulan, hari, dan hari besar atau hari raya sebanyak 1 kali kesalahan, dan huruf kapital dipakai sebagai huruf pertama nama geografis sebanyak 1 kali kesalahan.

8. Kartika. W terdapat 4 kesalahan dalam karangan yang dia tulis, diantaranya dalam penulisan huruf kapital sebagai huruf pertama awal kalimat sebanyak 3 kali kasalahan, dan huruf kapital dipakai sebagai huruf pertama nama geografis sebanyak 2 kali kesalahan.

9. Rufita Ayu terdapat 5 kesalahan dalam karangan yang dia tulis, diantaranya dalam penulisan huruf kapital Huruf kapital sebagai huruf pertama awal kalimat sebanyak 2 kali kesalahan, huruf kapital dipakai sebagai huruf pertama nama tahun, bulan, hari, dan hari besar atau hari raya sebanyak 1 kali kesalahan, dan huruf kapital dipakai sebagai huruf pertama nama geografis sebanyak 2 kali kesalahan.

10. Rafli Yulmaren terdapat 4 kesalahan dalam karangan yang dia tulis, diantaranya dalam penulisan huruf kapital sebagai

362 | Jurnal Kredo Vol. 2 No. 2 April 2019 huruf pertama awal kalimat sebanyak 1 kali kesalahan, huruf kapital dipakai sebagai huruf pertama nama geografis terdapat 2 kali kesalahan, dan huruf kapital dipakai sebagai huruf pertama unsur-unsur nama orang, termasuk nama julukan dan singkatan terdapat 1 kali kesalahan.

11. Ahmad Suhaimi terdapat 5 kesalahan dalam karangan yang dia tulis, diantaranya dalam penulisan huruf kapital sebagai huruf pertama awal kalimat sebanyak 1 kali kesalahan, huruf kapital dipakai sebagai huruf pertama nama geografis sebanyak 1 kali kesalahan, huruf kapital dipakai sebagai huruf pertama unsur-unsur nama orang, termasuk nama julukan dan singkatan sebanyak 2 kali kesalahan, dan huruf kapital dipakai sebagai huruf pertama setiap kata agama, kitab suci, dan Tuhan, termasuk sebutan dan kata ganti untuk Tuhan sebanyak 1 kali kesalahn.

12. Irwandi Agustian terdapat 4 kesalahan dalam karangan yang dia tulis, diantaranya dalam penulisan huruf kapital sebagai huruf pertama awal kalimat sebanyak 1 kali kesalahan, huruf kapital dipakai sebagai huruf pertama nama geografis sebanyak 1 kali, dan huruf kapital dipakai sebagai huruf pertama unsur-unsur nama orang, termasuk nama julukan 
dan singkatan sebanyak 2 kali kesalahan.

13. Ika Wintarti terdapat 6 kesalahan dalam karangan yang dia tulis, diantaranya dalam penulisan huruf kapital sebagai huruf pertama awal kalimat sebanyak 1 kali kesalahan, huruf kapital dipakai sebagai huruf pertama nama tahun, bulan, hari, dan hari besar atau hari raya 1 kali kesalahan, Huruf kapital dipakai sebagai huruf pertama nama geografis sebanyak 2 kali kesalahan, dan huruf kapital dipakai sebagai huruf pertama unsur-unsur nama orang, termasuk nama julukan dan singkatan sebanyak 2 kali kesalahan.

14. Nabila Dwi terdapat 6 kesalahan dalam karangan yang dia tulis, diantaranya dalam penulisan huruf kapital sebagai huruf pertama awal kalimat sebanyak 1 kali kesalahan, huruf kapital dipakai sebagai huruf pertama nama tahun, bulan, hari, dan hari besar atau hari raya sebanyak 1 kali kesalahan Huruf kapital dipakai sebagai huruf pertama nama geografis sebanyak 2 kali kesahan, huruf kapital dipakai sebagai huruf pertama unsurunsur nama orang, termasuk nama julukan dan singkatan sebanyak 1 kali kesalahan, dan huruf kapital dipakai sebagai huruf pertama setiap kata agama, kitab suci, dan Tuhan, termasuk sebutan dan kata ganti untuk
Tuhan sebanyak 1 kali kesalahan.

15. Natalia terdapat 4 kesalahan dalam karangan yang dia tulis, diantaranya dalam penulisan huruf kapital sebagai huruf pertama awal kalimat sebanyak 1 kali kesalahan, huruf kapital dipakai sebagai huruf pertama nama geografis sebanyak 2 kali kesahan, dan huruf kapital dipakai sebagai huruf pertama setiap kata agama, kitab suci, dan Tuhan, termasuk sebutan dan kata ganti untuk Tuhan sebanyak 1 kali kesalahan.

16. Dipa Wahidah terdapat 4 kesalahan dalam karangan yang dia tulis, diantaranya dalam penulisan huruf kapital sebagai huruf pertama awal kalimat sebanyak 1 kali kesalahan, huruf kapital dipakai sebagai huruf pertama nama tahun, bulan, hari, dan hari besar atau hari raya sebanyak 1 kali kesalahan, huruf kapital dipakai sebagai huruf pertama nama geografis 1 kali kesalahan, dan huruf kapital dipakai sebagai huruf pertama unsur-unsur nama orang, termasuk nama julukan dan singkatan sebanyak 2 kali kesalahan.

17. Risqi Aulia terdapat 5 kesalahan dalam karangan yang dia tulis, diantaranya dalam penulisan huruf kapital sebagai huruf pertama awal kalimat sebanyak 1 kali kesalahan, huruf kapital dipakai sebagai huruf pertama nama tahun, bulan, hari, dan hari 
besar atau hari raya sebanyak 1

kali kesalahan, huruf kapital dipakai sebagai huruf pertama nama geografis sebanyak 2 kali kesalahan, dan huruf kapital dipakai sebagai huruf pertama unsur-unsur nama orang, termasuk nama julukan dan singkatan sebanyak 1 kali kesalahan.

18. Dwi Rizki terdapat 6 kesalahan dalam karangan yang dia tulis, diantaranya dalam penulisan huruf kapital sebagai huruf pertama awal kalimat sebanyak 2 kali kesalahan, huruf kapital dipakai sebagai huruf pertama nama geografis sebanyak 1 kali kesalahan, huruf kapital dipakai sebagai huruf pertama unsurunsur nama orang, termasuk nama julukan dan singkatan sebanyak 2 kali kesalahan, dan huruf kapital dipakai sebagai huruf pertama setiap kata agama, kitab suci, dan Tuhan, termasuk sebutan dan kata ganti untuk Tuhan sebanyak 1 kali kesalahan.

19. Andina Putri terdapat 7 kesalahan dalam karangan yang dia tulis, diantaranya dalam penulisan huruf kapital sebagai huruf pertama awal kalimat sebanyak 1 kali kesalahan, huruf kapital dipakai sebagai huruf pertama nama geografis sebanyak 3 kali kesalahan, huruf kapital dipakai sebagai huruf pertama unsur-unsur nama orang, termasuk nama julukan dan singkatan sebanyak 2 kali kesalahan, dan huruf kapital dipakai sebagai huruf pertama setiap kata agama, kitab suci, dan Tuhan, termasuk sebutan dan kata ganti untuk Tuhan sebanyak 1 kali kesalahan.

20. Mad Soleh terdapat 5 kesalahan dalam karangan yang dia tulis, diantaranya dalam penulisan huruf kapital sebagai huruf pertama awal kalimat sebanyak 1 kali kesalahan, huruf kapital dipakai sebagai huruf pertama nama geografis sebanyak 2 kali kesalahan, huruf kapital dipakai sebagai huruf pertama unsurunsur nama orang, termasuk nama julukan dan singkatan sebanyak 1 kali kesalahan, dan huruf kapital dipakai sebagai huruf pertama setiap kata agama, kitab suci, dan Tuhan, termasuk sebutan dan kata ganti untuk Tuhan sebanyak 1 kali kesalahan.

Setelah hasil rekapitulasi frekuensi penggunaan huruf kalital di atas maka dapat dipresentasekan kesalahan penggunaan huruf kapital mahasiswa semester 3 universitas Indraprasta sebagai berikut: 


\section{Tabel 2}

\section{Presentase Kesalahan Huruf Kapital}

\begin{tabular}{|c|l|c|c|}
\hline No & \multicolumn{1}{|c|}{ Aspek Kesalahan } & $\begin{array}{c}\text { Jumlah } \\
\text { Kesalahan }\end{array}$ & Presentase \\
\hline 1 & $\begin{array}{l}\text { Huruf kapital dipakai sebagai huruf pertama } \\
\text { awal kalimat }\end{array}$ & $\mathbf{2 5}$ & $\mathbf{2 5 \%}$ \\
\hline 2 & $\begin{array}{l}\text { Huruf kapital dipakai sebagai huruf pertama } \\
\text { nama tahun, hari, bulan, hari besar atau hari } \\
\text { raya. }\end{array}$ & $\mathbf{1 0}$ & $\mathbf{1 0} \%$ \\
\hline 3 & $\begin{array}{l}\text { Huruf kapital dipakai sebagai huruf pertama } \\
\text { nama geografis. }\end{array}$ & $\mathbf{3 5}$ & $\mathbf{3 4} \%$ \\
\hline 4 & $\begin{array}{l}\text { Huruf kapital dipakaisebagai huruf pertama } \\
\text { unsur-unsur nama orang termasuk nama } \\
\text { julukan dan singkatan. }\end{array}$ & $\mathbf{2 3}$ & $\mathbf{8 3} \%$ \\
\hline 5 & $\begin{array}{l}\text { Huruf kapital dipakai sebagai huruf pertama } \\
\text { setiap kata agama, kitab suci, dan Tuhan, } \\
\text { termasuk sebutan dan kata ganti untuk } \\
\text { Tuhan }\end{array}$ & $\mathbf{8}$ & \\
\hline
\end{tabular}

Persentase kesalahan penggunaan huruf kapital di atas menggunakan rumus perhitungan sebagai berikut:

\begin{tabular}{|c|c|}
\hline $\begin{array}{c}\text { Aspek } \\
1\end{array}$ & $\sum=\frac{\mathbf{2 5}}{\mathbf{1 0 1}} \times 100 \%=25 \%$ \\
\hline $\begin{array}{c}\text { Aspek } \\
2\end{array}$ & $\Sigma=\frac{\mathbf{1 0}}{\mathbf{1 0 1}} \times 100 \%=10 \%$ \\
\hline $\begin{array}{c}\text { Aspek } \\
3\end{array}$ & $\Sigma=\frac{\mathbf{3 5}}{\mathbf{1 0 1}} \times 100 \%=34 \%$ \\
\hline $\begin{array}{c}\text { Aspek } \\
4\end{array}$ & $\Sigma=\frac{\mathbf{2 3}}{\mathbf{1 0 1}} \times 100 \%=23 \%$ \\
\hline $\begin{array}{c}\text { Aspek } \\
5\end{array}$ & $\Sigma=\frac{\mathbf{8}}{\mathbf{1 0 1}} \times 100 \%=8 \%$ \\
\hline
\end{tabular}

\section{Penafsiran dan Uraian Penelitian}

Berdasarkan hasil analisis kesalahan penggunaan huruf kapital pada karangan deskripsi Mahasiswa Semester 3 yang mengikuti mata kuliah menulis di atas, maka dapat diuraikan seberapa besar presentase penggunaan huruf kapital mengenai: 1) Huruf kapital dipakai sebagai huruf pertama awal kalimat, sebanyak 25 kesalahan dengan jumlah presentase 25\%. 2) Huruf kapital dipakai sebagai huruf pertama nama tahun, hari, bulan, hari besar atau hari raya, sebanyak 10 kesalahan dengan jumlah presentase 10\%. 3) Huruf kapital dipakai sebagai huruf pertama nama geografis, sebanyak 35 kesalahan dengan jumlah presentase 34\%. 4) Huruf kapital dipakaisebagai huruf pertama unsur-unsur nama orang termasuk nama julukan dan singkatan, sebanyak 23 kesalahan dengan jumlah presentase $23 \%$. 5) Huruf kapital dipakai sebagai huruf pertama setiap kata agama, kitab 
suci, dan Tuhan, termasuk sebutan dan kata ganti untuk Tuhan, sebanyak 8 kesalahan dengan jumlah presentase $8 \%$.

\section{SIMPULAN}

Berdasarkan penelitian dan pendeskripsian mengenai kesalahan penggunaan huruf kapital pada karangan deskripsi mahasiswa Semester 3 (R3A) yang mengikuti mata kuliah menulis Universitas Indraprasta PGRI, dapat disimpulkan bahwa terdapat sebanyak 101 kesalahan dalam menggunakan huruf kapital dari 20 karangan deskripsi Mahasiswa semester 3 kelas R3A yang meliputi: 1) Huruf kapital dipakai sebagai huruf pertama awal kalimat, sebanyak 25 kesalahan dengan jumlah presentase 25\%. 2) Huruf kapital dipakai sebagai huruf pertama nama tahun, hari, bulan, hari besar atau hari raya, sebanyak 10 kesalahan dengan jumlah presentase 10\%. 3) Huruf kapital dipakai sebagai huruf pertama nama geografis, sebanyak 35 kesalahan dengan jumlah presentase 34\%. 4) Huruf kapital dipakai sebagai huruf pertama unsur-unsur nama orang termasuk nama julukan dan singkatan, sebanyak 23 kesalahan dengan jumlah presentase 23\%. 5) Huruf kapital dipakai sebagai huruf pertama setiap kata agama, kitab suci, dan Tuhan, termasuk sebutan dan kata ganti untuk Tuhan, sebanyak 8 kesalahan dengan jumlah presentase $8 \%$.

Dari analisis di atas maka dapat disimpulkan bahwa penggunaan huruf kapital di pakai sebagai huruf pertama nama geografis merupakan kesalahan yang paling dominan dari seluruh aspek kesalahan pada penelitian ini. Dan dapat dikatakan bahwa kesalahan penggunaan huruf kapital pada karangan deskripsi mahasiswa semester 3 (R3A) Universitas Indraprasta PGRI dikategorikan cukup baik, kurang dari 50\%. Karena Mahasiswa sebenarnya sudah mengetahui kaidah penulisan yang baik, hanya saja perlu bimbingan dan pemahaman serta seringnya praktik langsung dalam menulis. Agar Mahasiswa terbiasa menggunakan aturan penulisan sesuai PUEBI yang berlaku.

\section{DAFTAR PUSTAKA}

Hasani, A. 2005. Ihwal Menulis. Banten: UNTIRTA Press.

Matanggui, Junaiyah. H dan E. Zaenal Arifin. 2014. Analisis Kesalahan Berbahasa Indonesia. Tangerang: Pustaka Mandiri.

Prihantini, Ainia. 2015. Master Bahasa Indonesia. Yogyakarta: B. First. 
Tarigan, Henry Guntur. 2011. Pengajaran Analisis Kesalahan Berbahasa. Bandung: Angkasa.

Semi, M. Atar. 2012. Metode Penelitian Sastra. Bandung: Angkasa.

Sugiyono. 2016. Metode Penelitian Kuantitatif, Kualitatif dan R\&D. Bandung: PT Alfabet. 